\title{
後頭蓋窩疾患に対する神経耳科学的検討
}

-Part VI 聴覚誘発電位の郜床一

\author{
深谷卓・小松崎 篤
}

\section{Neuro-otological Findings on the Posterior Fossa Lesions}

\author{
- Part VI Auditory Evoked Potentials and Its Clinical Significance- \\ Takashi Fukaya and Atsushi Komatsuzaki \\ Department of Oto-rhinolaryngology, University of Tokyo
}

\section{I はじめに}

聴覚誘発電位の臨床は electronicsの発展と歩をそろえ

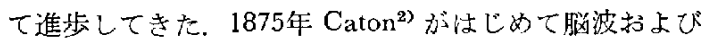
大脳の誘発電位を記載した時に注 galvanometer が使用 され，増幅器もオシロスコープも存在しなかった。この 脱波を他覚的聴鸴検查法として使用し始めたのは第二次 世界大戦後で, average computer の導大がきっかけとな った。しかし替時が50〜500 mseck出現する聴性大腷誘 発電位は，1)睡眠や意識水準に反応が左右されやナい， 2)再現性が十分でない，3）末梢の中耳・内耳障䞳と高次 神経系障害の鑑则ができない，などの闍題点があり信頼 性に之しかった。

增幅度が高く, SN 比の良々増幅器の開発により, 聴 覚誘発電位中の低電位の潜時の短い成分が検出できるよ

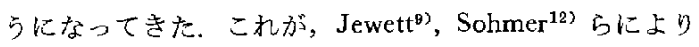
1970年に報告された 聴性媨幹反応 (auditory brainstem response-以下 ABR 上略す) である. ABR は far field potential で7個のピークを持ち，潜時は10 $\mathrm{msec}$ 以内で あり, 反応が安定し、末梢聴賞障害では自覚域值とABR 域值が近似するなどの特徴をもち，他覚的㯖力検查法と して有力な手段となっている.

この上うな頭皮上の誘発電位とは別に，1967年に Yoshie ${ }^{16)}$,Portman ${ }^{11)}$ らによって, 人間の聴神経の活動
電位が記録され始めた(蝸電図)，螖電図は ABRよりも はやい反心であり, 中耳・内耳の末梢聴器の障害の病態 生理, および末梢性の難聴の他覚的聴力検查手段として 用いられている。

このように㯖覚誘発電位の歴史は electronicsの発達の 歷史でありままた他覚的聴力検查法の歴史でるあった。 しかし最近になり，蝸電図，聴性脳幹反応が神経疾患一 応用され，後期成分も高次神経系一応用される，など聴 覚誘発電位と神経学, 実験心理学との結びつきが強くな ってきている。

本稿では蝸電図，ABR を中心として，聴覚誘発電位 の種類とその後頭盖疾患への応用についての知見を述心 る.

\section{I 聴覚誘発電位の種類と応用 (表 1)}

表 1 に Davis ${ }^{32}$ らの分類をめげる。誘発電極の位固で 蛊電図と vertex potentials が区分され，後者はさらに潜 時により，速反応，中間反応，緩反心分玑れる。

1. 蚟電図 (electrocochleogram) (図 1 A)

1967年に Yoshic ${ }^{153}$ ，Portman ${ }^{11}$ らにより非観血的に記 録されるよらになった電位で，電極を経鼓膜的に岬角に 犆く.内耳有毛細胞由来の蝸牛マイクロホン電位 $(\mathrm{CM})$, summating potential (SP) が潜時0から始まり，聴神経 の複合活動電位 (AP) が $1 \sim 4 \mathrm{msec}$ 内に現れる. 3 者は

[連絡先： $\overline{7} 113$ 東京都文京区本郷7-3-1，東京大学耳鼻咽喉科，小松崎篤] 
表 1 聴覚誘発電位の分類

\begin{tabular}{|c|c|c|c|c|}
\hline \multirow{2}{*}{ 蝸 } & 名 & 称 & $\begin{array}{c}\text { 潜時 } \\
\text { (msec) }\end{array}$ & 起 源 \\
\hline & 蝸牛マイク & 電位 (CM) & 0 & 外有毛細胞 \\
\hline 電 & Summating & tial (SP) & 0 & 外有毛細胞 \\
\hline 図 & 複合活動電 & & $1 \sim 4$ & 蝸 牛神経 \\
\hline
\end{tabular}

1. 速反応 (fast response)

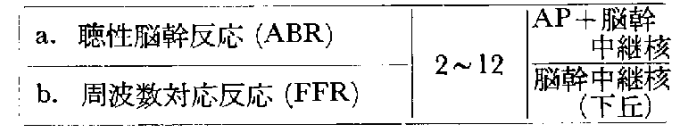

2. 中閒反応 (middle response)

\begin{tabular}{|c|c|c|}
\hline a. 中閒潜時反応 (MLC) & $12 \sim 50$ & $\begin{array}{r}\text { 内侧膝状体 } \\
\sim \text { 㯖皮質 }\end{array}$ \\
\hline b. 筋原性反芯 & $12 \sim 25$ & 耳介・側頭筋 \\
\hline \multicolumn{3}{|l|}{ 3. 楥反応 (slow response) } \\
\hline a. 頭頂部緩反応 & $50 \sim 800$ & $\mid \begin{array}{l}\text { 第 } 2 \text { 次 } \\
\text { 聴皮質 }\end{array}$ \\
\hline \multicolumn{3}{|l|}{ 4. 後反応 (late response) } \\
\hline a. $\mathrm{P}_{300}$ & $250 \sim 600$ & 大媨皮質連 \\
\hline b. $\mathrm{CNV}$ & DC shift & \\
\hline
\end{tabular}

分離可能であり，電位発生部位と誘導電極が接近してい るので，反応は明確で加算回数も少なくてすむ．反応は 意傤水準に左右されず域值る小さく，ほぼ自党域值に等 しい5716117. このために蝸電図は中耳・内耳・德神経由来 の難㯖の他覚的検查としては一番鋭敏なるのといえる。 また SP.CM 等を利用し, メニエール病や突発難㯖の病 態生理の解明にる利用される。

\section{Vertex potential}

1) 速反応 (fast response)

a. 聴性脑幹反応 (auditory brainstem response)

近年もっともさかんに研究・臨床応朋されている聴覚 誘発電位である，記録结関電極を頭頂部に，不関電極を 検查側乳突部に，そして反対側乳突部を接地する。100 $\mathrm{dB}$ 以上の gain 在つ増幅器を使い1,000 2,000回加算 する。フィルターにより反応波形はかなり変化する。音 刺澈にはクリックまたは，高周波数の tonepip を使う。 反応反形は図1Bのよらに7つのピークに分離する。こ のwave I 〜 VIIの起源についてはネコによる破薯と切 断実験，およびヒトの剖唡所見に基つくるのがある。 Buchwald \& Huang ${ }^{13}$ らは wave I : 同側の聴神経幹, wave II : 㢄側の蝸牛神経㮎, wave III：反対側の上オリ -ブ核, wave IV : 両側の外側毛帯核, wave $\mathrm{V}$ : 反対側 の下丘と説明している，破填切断実験で驻注ほ上記の対
応が成立するが，破壊により消失した wave は，必ずし も破壞された部位よりのみ生じたとは結論しえない。 Starr ${ }^{13)}$ らはヒトで死亡直前の ABR を記録しここれと部 検所見を対比しているが，必ずしる各 wave と各神経核 は 1 対 1 の対応をしていない. Wave I が AP，つまり 同側の聴神経幹由来であることは確実であるが, wave II 以降性反応の起源法性っきりとは加っていない，

ABR は乳幼览の聴覚障害診断に必須である。その理由 は生下児から明瞭な反応がえられ，間接的に中耳・内 耳の末梢聴力が推定しえるからである。この目的には wave $\mathrm{V} か ゙$ 振幅が大きく，かつ自覚域值に近い弱以音刺 激でも出現するので指標とされる。し加しABRには 低音域では末梢聴力が測定しえない弱点を有している $\left(\right.$ Davis $\left.^{4)}\right)$ ，脳幹障害の診断にはクリックによる強い音刺 激が用いられる。

b. 周波数対忘反応 (frequency following response) ABR と同じ記録法にて，刺激した周波数とまったく 同一の周波数の反応が得られる，特に低音刺激で出現寸 るが，刺激している部位は高音城とされる，起源は訤幹 中継核，特に下丘ぶ示唆されている。

2) 中間反応 (middle response $12 \sim 50 \mathrm{msec}$ )

a. 中間潜時反忘 (middle latency component, MLC) (図 $1 \mathrm{C}$ )

1958年に Geisler?゙より報告されたが，最近まであ まり注目されなかった。記録法は ABR と同じである が，分析時間を $50 \mathrm{msec}$ とする. ABR に続いて出現す る NoPoNaPaNb と呼ば狄る成分をさす，内側凌状体， 聴放線，第一次聴皮質に起源があるとされている．現在 ABR と組み合わせて他党的聴力検查に用いられている.

b. 筋原性反応 (myogenic response)

$\mathrm{ABR}$ や MLC の記録時に10 25 msec の潜時で現れ るきわわて大電位の反応で後耳介笳や側頭筋の反応であ る。 反忘に安定性加疗く，あまり使われない。

3) 緩反応 (slow response: $50 \sim 250 \mathrm{msec}$ )

a. 頭頂部緩反忘 (slow vertex response) (図11 D)

従来訤波聴検として用いられた成分で，覚醒時には50 $\sim 300 \mathrm{msec}$ ，睡貤时には100 400msec に出現する $\mathrm{P}_{1} \mathrm{~N}_{1}$ $\mathrm{P}_{2} \mathrm{~N}_{2}$ のピークを持っ反応である。起源は不明であるが， 第 2 次㯖皮質の非特異的反店と考它られている。この反 応は再現性が悪く，睡眠㳭度でピークの消失や潜時が変 わり，しばしば判定に困難なことがある。現在では他覚 的な聴力検查法としては ABR にとって変られている が，ABR，MLC と比較しつつ大媨レベル，特に側頭葉 疾患の診断に利用されている(加我 $\left.{ }^{10)}\right)$ 。

4) 後反忘 (late response: $250 \mathrm{msec} \sim$ ) 

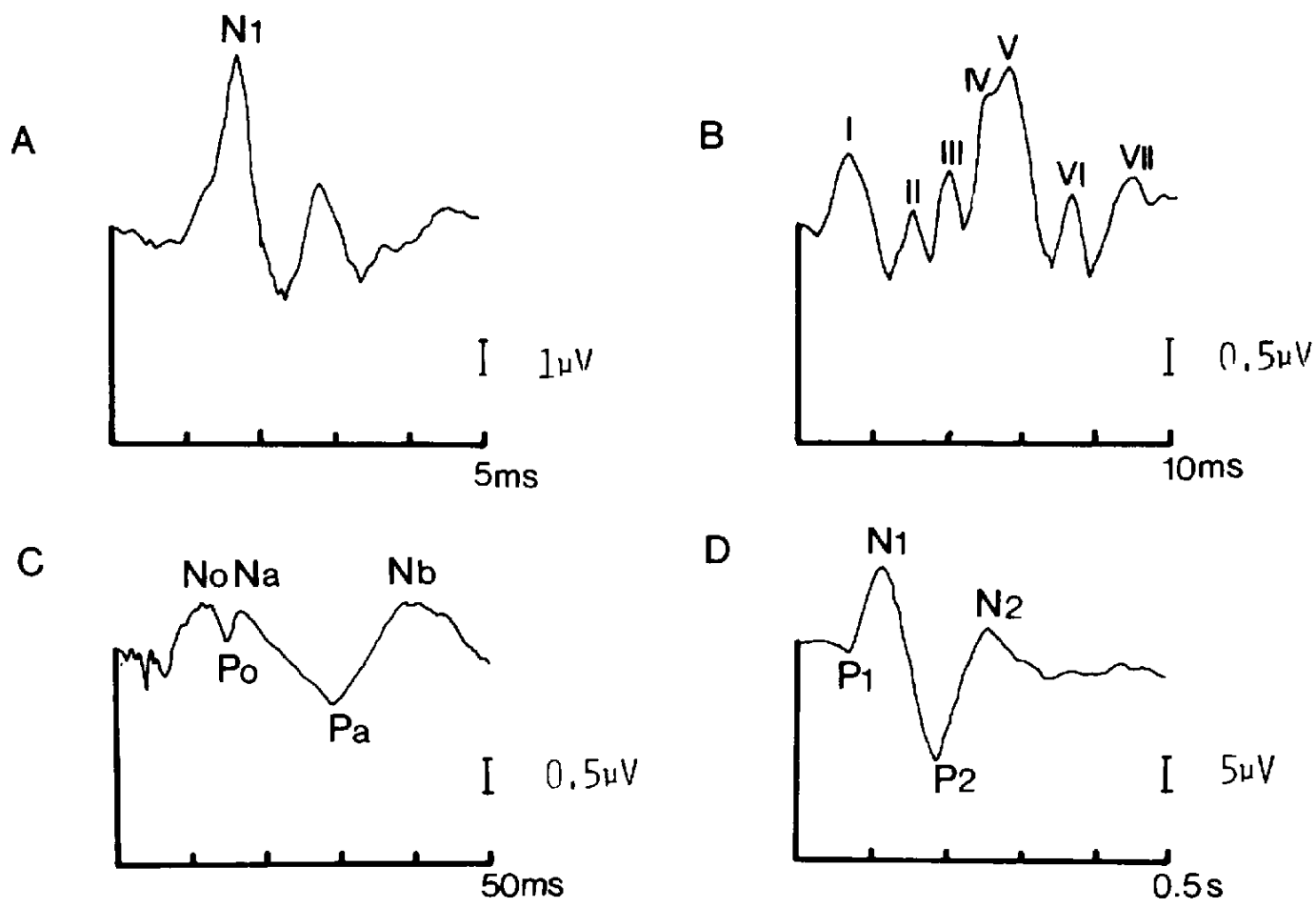

図 1 音刺激による誘発電位

A：蛤電図 (electrocochleogram) 鼓室岬誘道の記録で，60dB HLのクリック刺激で512回加算している，刺激 を強くする上 $\mathrm{N}_{1}$ の平認められるようになる。刺激の位相を交互に変化し $\mathrm{CM}$ は消去している。

B : 聴性脑幹反忘 (auditory brainstcm response) wave I 〜 VII のピークを認める. Wave I 沬 AP と同じ, wave II 以降のピークの起源は本文参照. 刺激は $60 \mathrm{dBHL} ク リ ッ ク ， 2,000$ 回加算.

$\mathrm{C}$ : 中間潜時反応 (middle latency component) NoPoNaPaNb tさす. ABR に続いて現れる。刺激は60dB HL クリック，1,000回加算.

$\mathrm{D}$ : 頭頂部緩反応 (slow vertex potential) $\mathrm{P}_{1} \mathrm{~N}_{1} \mathrm{P}_{2} \mathrm{~N}_{2}$ 成分をさす。潜時 $50 \sim 300 \mathrm{msec}$ に出現している. 覚醒時の 反応であり，刺激は $1 \mathrm{KHz}, 60 \mathrm{~dB}, 256$ 回加算. $\mathrm{A}$ 加ら Dまですべて同一例（正常聴力）の記録である。

a. $P_{300}$ 後期陽性波 (late positive component)

被験者に一連の刺激音の中加特定の刺激音 (task relevant stimulus) 在数えさせることにより，潜時250〜 $600 \mathrm{msec} て ゙$ 現れる陽性波である。選択的注意集中と誘発 電位を結んだ めのである。

b. CNV (contingent negative variation)

条件ふうけに伴い現れる陰性の電位変化である。クリッ ク音刺激を条件刺激としでフフラッシュを命令刺激しす る、フラッシニはポタンで被験者が止められる。音刺激 がありフラッシュが光ったのでボタンで止めようとす る時から CNVが現れる。ただリックとフラッシュで 刺激してを現れない，条件ゔけが完成すると音刺激だけ でも反応が出現するがすぐに消失してゆく，CNV 沬心 因性難聴などに利用されている。

\section{II後頭蓋窝疾患への応用}

図 2 に聴性誘発電位の部位䛦断の可能性を示した，中 耳疾患には中耳炎, 中耳外稘，耳小骨奇型汃，内耳疾患 にはメニエール病, 突発難㯖や各種の感音難聴が含まれ る. 中耳・内耳の診断に㤯電図が一番有力であり，病

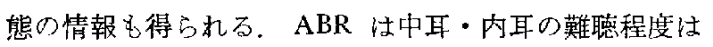
推定し5るが，而者の鑑別は困䨅である。さしろABRは 聴神経から下丘までの鑑别に有少である，MLC や頭頂 部緩反心は未稍聴力の決定には不利で，MLC は内側滕

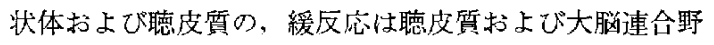
の局在診断にむく。

したがって後頭蓋窝疾患に応用できるのは，螖電図と $\mathrm{ABR}$ のつである。

螖電図は AP.SP·CM 老記録することで，内耳病変と 蝸牛神释病変を同時に，かつ別々に評価しえる利点があ 

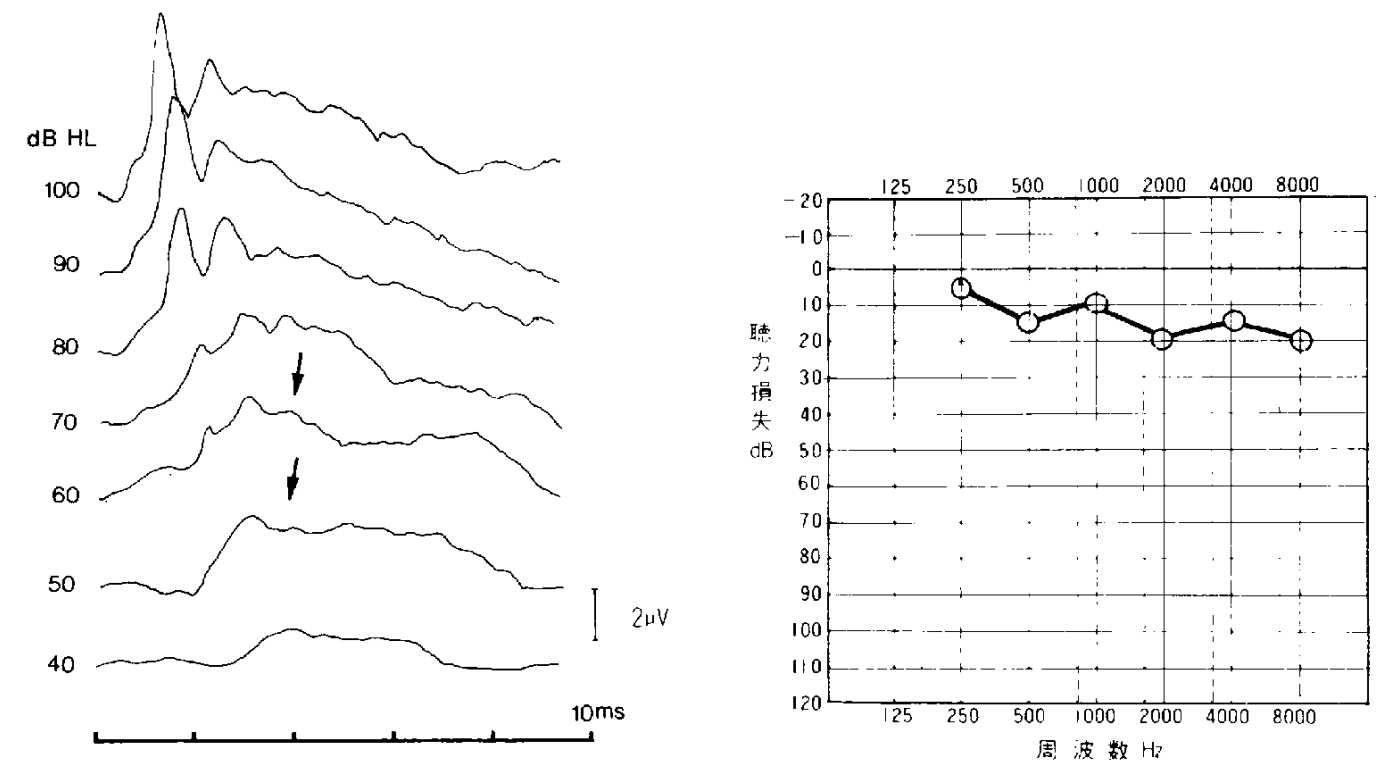

図 2 比較的小さな聴神経腫湟の蝸電図

右に純音聴力図を示す。螖電図では AP を指標とした域值検查では $10 \mathrm{~dB}$ まで検出しえた。 $6 \mathrm{msec}$ 以上の幅を むつ AP 波形の拉大が特徴的である。刺激間隔を狭めるとこの AP 波形の掂大は消失するので SP ではないこと がわかる．刺激はクリック，鼓室岬誘導である，図 5 Aと同じ症例である。

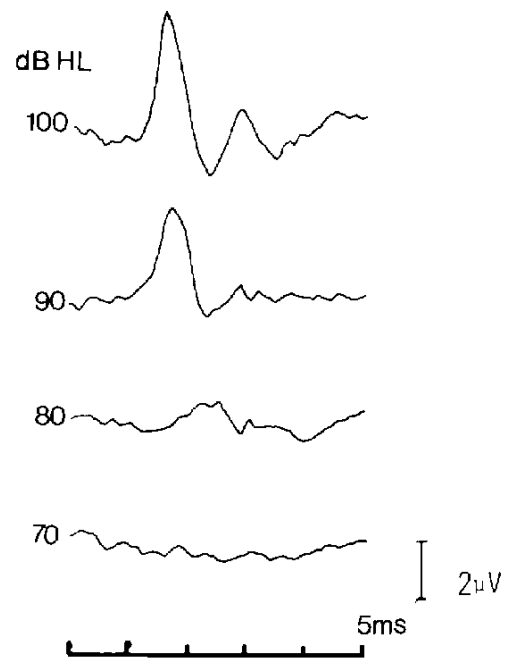

因 3 大きな聴神経腫瘍の蝸電図

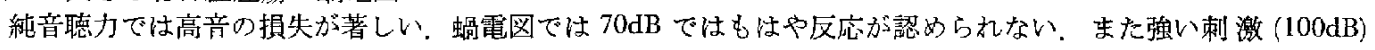
でも $\mathrm{N}_{1}, \mathrm{~N}_{2}$ が分離している，CM の振幅が著しく小さいこととるまわせると内栍難聴が前面に出ていると解 せる。図 5 B の症例と同一である。

る.

Gibson $^{8)}$ らは螖牛神経病変, その大多数が小腷橋角 部病変を検討し，蝸電図の有用性について，(1)蝸牛マイ クロホン電位 $(\mathrm{CM})$ 任存される. (2) APを指標にした 域值桱查では純音媤力検查よりも低い刺激でも反忘があ る. (3) AP が broad になりがちである，の3 点から正

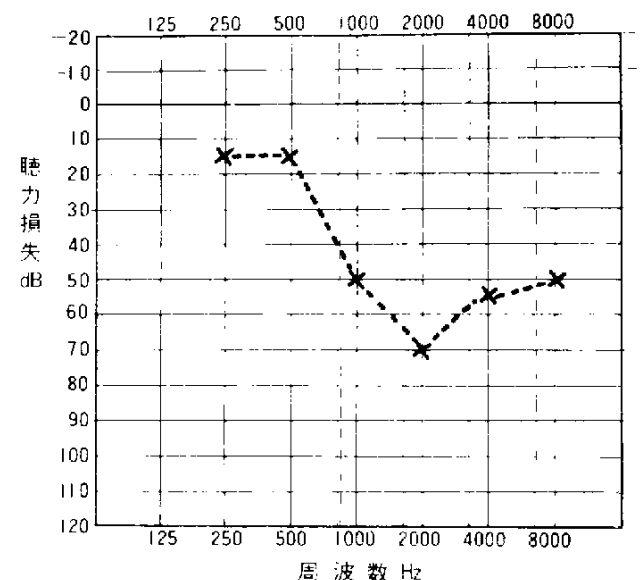

常な螖牛電気活働が这幹に伝わらないことが証せる上強 調している，Eggermont ${ }^{\mathrm{Q})} ら の$ 報告もほぼ同じ結果とな っている.

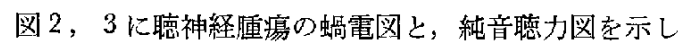
た。図 2 注比較的小さな腫瘍 $(15 \mathrm{~mm})$ で, 純音聴力は $10 \mathrm{~dB}$ ほどの感音難㯖を示す，蝸電図では $\mathrm{CM}$ はほほ 

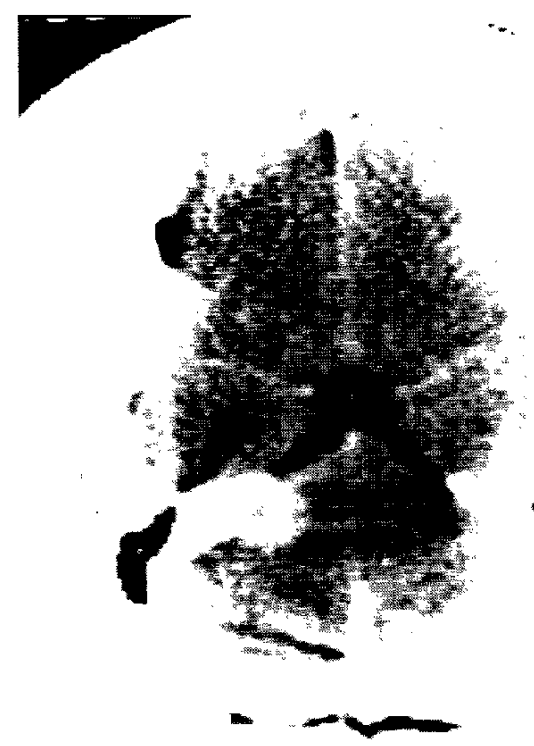

図 4 図 3 症例 $の C T$

表 2

中耳 内耳 聴神経 脳幹 内側 聴及質 聴営連 搸状体

\begin{tabular}{cccccccc} 
䖮電図 & 0 & 0 & 0 & 0 & $\times$ & $\times$ & $\times$ \\
\hline A B R & 0 & 0 & 0 & 0 & $\times$ & $\times$ & $\times$ \\
\hline ML C & 0 & 0 & 0 & 0 & 0 & 0 & $\times$ \\
\hline 頭頂部 & 0 & 0 & $\times$ & $\times$ & $\times$ & 0 & 0
\end{tabular}

(O) : 確実

○：推定しらる

X: 不可能

正常振幅で，SP の增大もない，AP は波形が broadなの が特徴的である(久印)。図了は図4のCTにみられる 上うに巨大な腫演の蝸電図である。純音聴力は高音域が 著しく墨以，蝸電図では $\mathrm{CM}$ の振幅は小さく，AP注强 い音刺激でのみ出現する。この蛤電図所見注内耳性難聴 に特徽的なるのであり，血行障害による螖牛障害が前面 に出ているものと考えられる。

このように, Gibson ${ }^{8)}$ らの報告は寸心゙ての後迷路障害 に当るわけではなく，直接侵潤や血行障害がなく内耳が 正常な例についてあてはまるわけであり，聴神経腫瘍で は比較的早期のむのの診断に有効であるといえる。

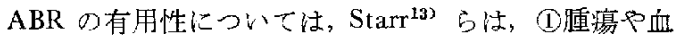
管障害に上万聴覚系の病巣を; 末梢, 橋, 中腷, 視床の

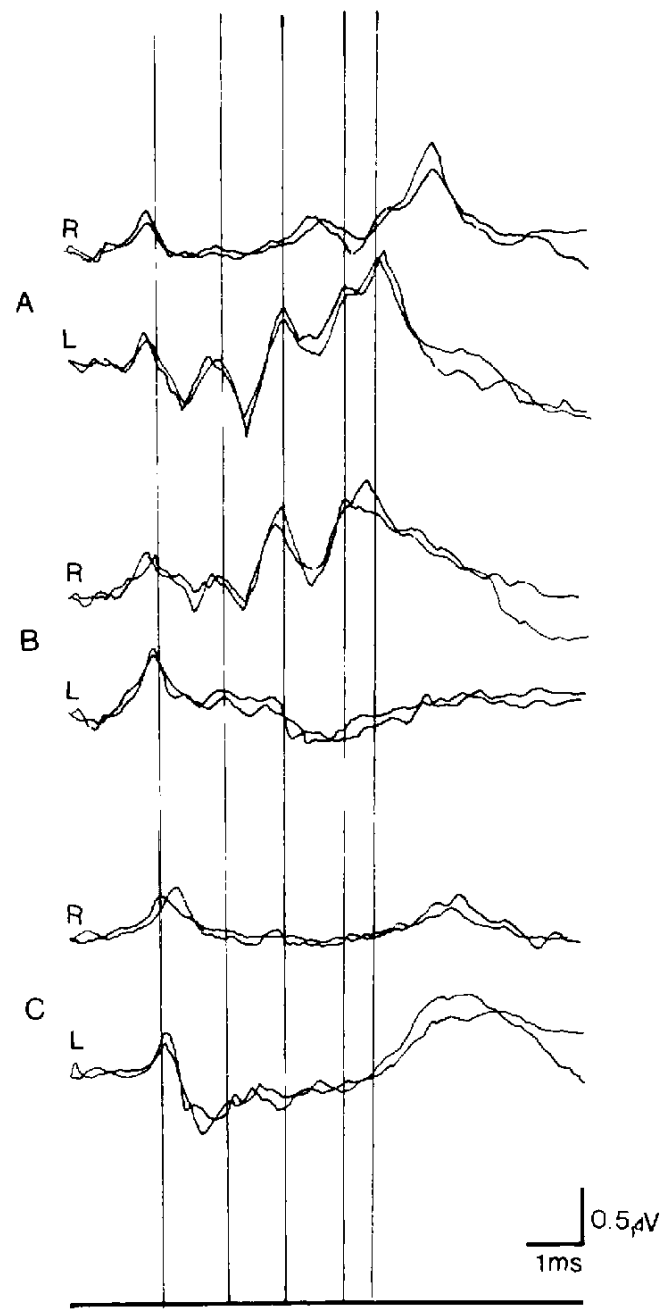

図 5 聴神経腫堭の ABR 3 例

A：25才男性。右患側。右刺激では wave III 以 降の延長と振幅の減少が著明である。左は正常.

B：48才男性．左患側。左刺激では wave I のみ認 められる。有は正常。

C：16才男性。レックリングハウゼン氏病で両側の 聴神経腫場を認觉。，Wave I 以降牥判然としない，

縦線は wave I〜Vの標準倬である。

レベルに分けて局在診断をする，(2)脳幹の変性疾患の局 在診断, (3)照睡状隼の時, 代謝性のもの加器質性変化な の加鑑別するとしている。しかし後頭蓋䆚疾患は必ずし もすべてが聴覚伝導路在侵すわけではなく，また脳幹で は左右の交又も多く、はっきりと中継核のレベルでの局 在診断はまだ困難といえる，

$\mathrm{ABR}$ 注睡眠媣度や通常の麻醉には影響されないが, 音 刺激の条件上フィルターに上り波形は著しく变化する. 


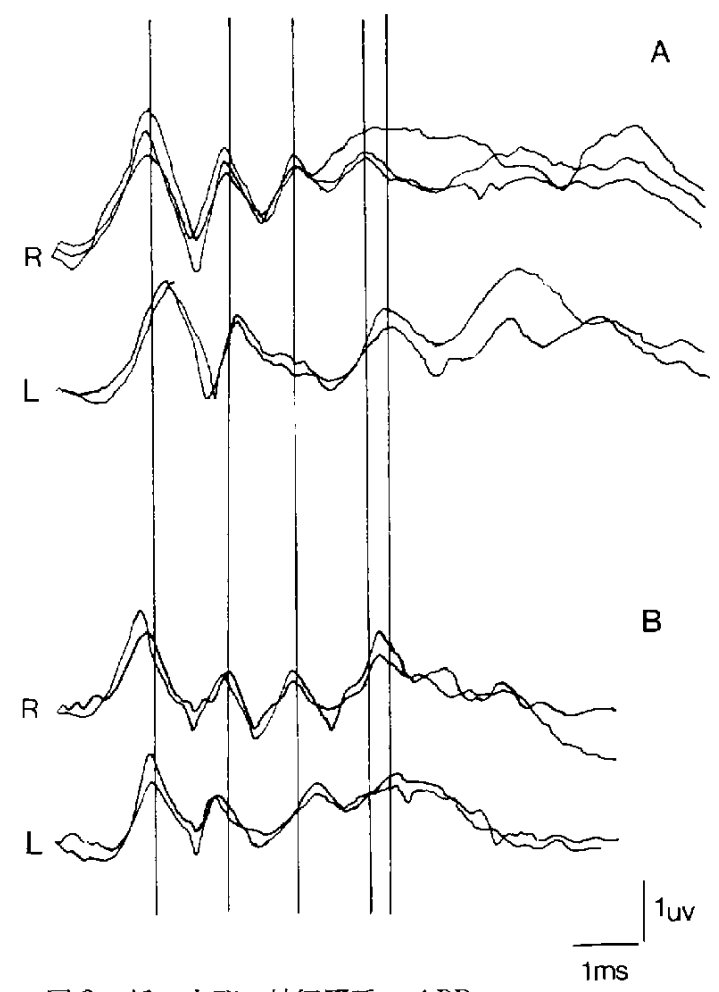

图 6 橋 - 中䍁の神経膠腫の $\mathrm{ABR}$

A：17才男性。否側注 wave I 〜 III まで正常であ るが, wave IV 以降は同定しえない，左側では wave II 以降汢ピークが潜時から同定できない。

B：43才男性。両側とも wave IV まで同定しえる が, wave $\mathrm{V} か ゙$ 消失している。

綐線は wave I $\sim \mathrm{V}$ の裂準值者示吉.

神経学的に応用する場合はクリックで強い刺激を与える のが好ましい。

脑幹障害弆 $A B R$ でみる場合には，波形の変化と潜時

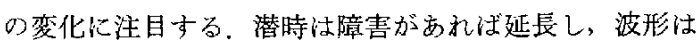
分離が悪くなったり，振幅が減少したり波が消失したり 古る。以下に媨幹の障害例の ABR を部位別に示す。

図 5 は小脳橋角部の神経鞘腫の3例である。症例A は 患側は右側で図 2 と同じ症例である。右耳刺激で wave IからVまく出現しているが， wave II 以降の潜時の延 長と振幅の減少が著しい，左は正常である。症例Bは図 3 と同じ症例である。左耳刺激では wave Iの諗めら

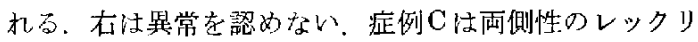
ングハウゼン病で，やや潜時の避れた wave I のみ認め られる。昜外の良性腫陽仕，大きさが小さい時は障害部 以降の波の潜時が延長し，健側に泣暴常がないことが多 W.

図 6 は橋の神程殄腫(A)と中㹸の神経膠腫(B)の ABR で

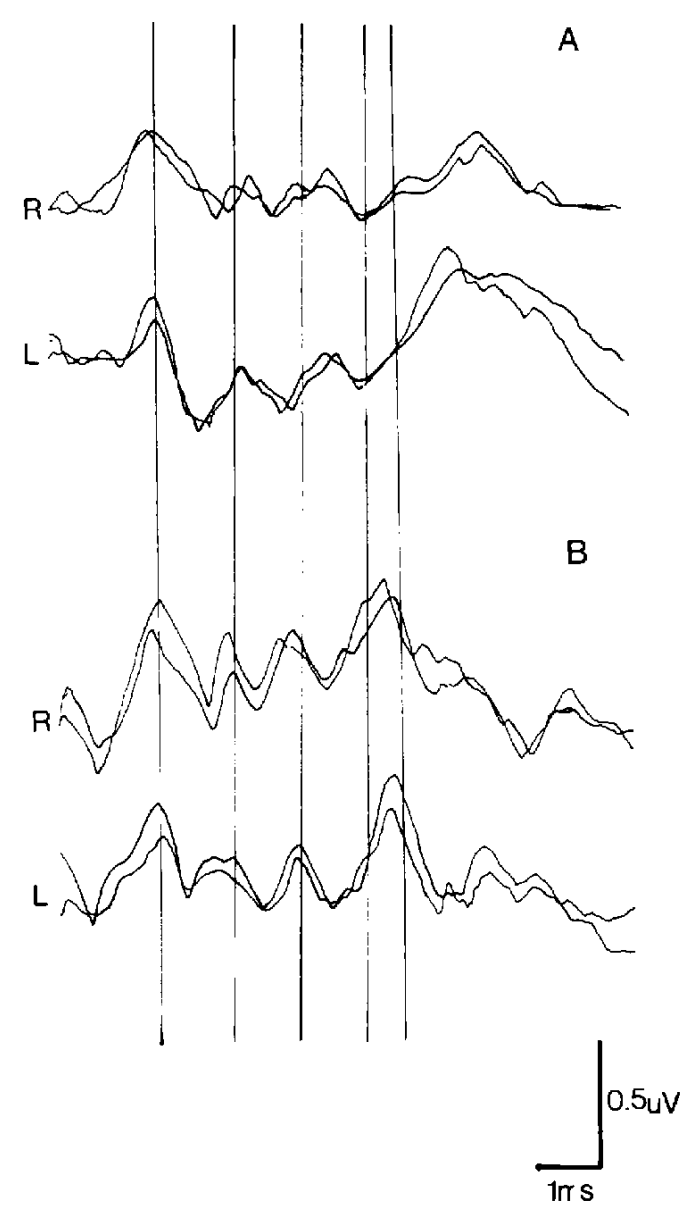

図 8 変性疾患の $\mathrm{ABR}$

A：28才男性，多発性硬化症。左右と马 wave II 以降の潜時の延長が著しい，特に右に著しい，

B：46才女性，替髄小腷変性症，左右とも正常であ 万.

就線は wave $\mathrm{I} \sim \mathrm{V}$ の標準徝を示す.

ある.図7 に症例 AのCT を示す，症例 A では右側 注 wavc I 〜 II までは正常であるが, wave IV 以降認め えない，しかし左側は wave II 以降はピーク形成があっ ても潜時から同定することが困難である。症例 Bでは左 右とも wave IVまて洨るが，振幅の大きいwave Vi 同定しえない：この症例のよらに ABR では蝸牛神経幹

・橋・中脳といった大まかな部位別診断仿可能であると 思わ扎る。

図 8 に変性疾患の ABR を示寸，A江多発性硬化症の 例で純音聴力は正常である。この例では wave III以降の 潜時の遅れが著しい， B は脊髄小脳変性症で左右とも正 常である。変性疾患では wave II以降の潜時が延長する のが特徴である。 


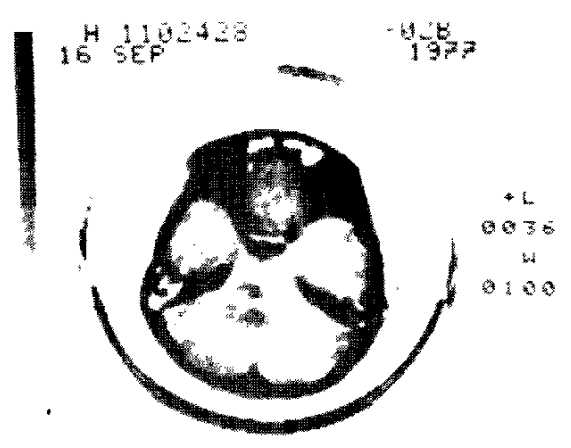

A

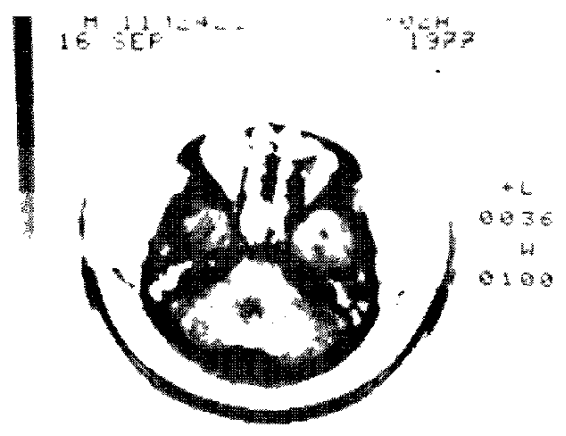

A

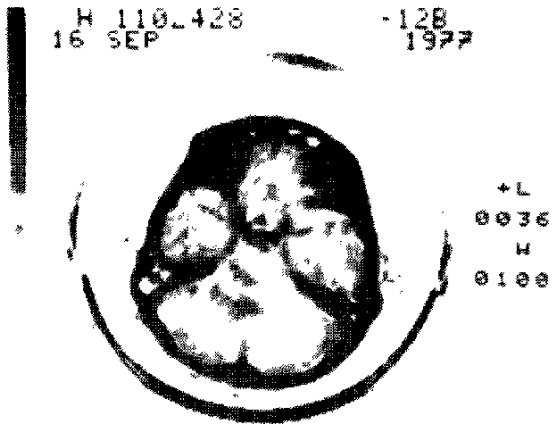

B

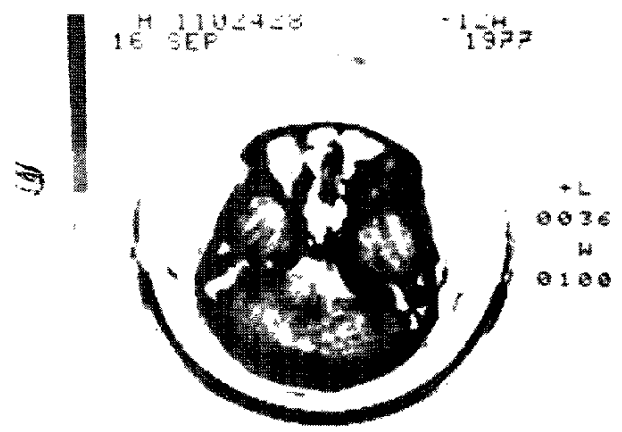

B

図 7 橋神経㺟腫の CT

ABR の限界恃，所見の異常のみで診断がつくわけで なく，神経学的所見や放射線診断学の補助手段である点 につきる、湷際以上の症例はABR 施行前に局在䜾断が ついている. しかし ABR はをの神経学的応用が始まっ たばかりであり，負荷検查を含め今後の発展が期待でき る梙查である。

\section{IV ま $ょ め$}

蝸電図，聴性膍幹反応を中心に，聴覚誘発電位の分類 とその後頭盖窝疾患への応用を述べた，他覚的聴覚検査 法のみならず脳幹, 高次聴覚系の機能検查として発屋普 及寸るものと考完られる。

\section{文献}

1) Buchwald, J. S. \& Huang, C.: Farfield acoustic response: Origins in the cat. Science 189: 282-284, 1975

2) CAton, R.: The electric currents of the brain. Br Med I 2: 278, 1875

3) Davis, H.: Principles of electric response audiometry. Ann Otol Rhinol Laryngol [Suppl] 28: $1-96,1976$
4) Davis, H. \& Hirse, S. K.: The audiometric utility of brain stem response to low-frequency sounds. Audiology 15: 181-195, 1976

5) Egcermont, J. J.: Electrophysiological investigation of the human cochlea. Audiology 13: $1-22,1974$

6) Egcermont, J. J.:Electrocochleography. In: Handbook of sensory physiology. Volume V/3. Springer-Verlag, New York, 1976

7) Geisler, C. D., Frishropf, L. S. \& Rosenblith, W. A.: Extracranial responses to acoustic click in man. Science 128: 1210-1211, 1958

8) Gleson, W. P. R. \& Beagley, H. A.: Transtympanic electrocochleography in the investigation of retro-cochlcar disorders. Rev Laryngol [Suppl] 97: 507-516, 1976

9) Jewett, D. L., Romano, M. N. \& Williston, J. S.: Human auditory evoked potentials; Possible brain stcm components detected on the scalp. Science 167: 1517-15]8, 1970

10) 加我弗孝, 小林逸郎, 進藤美津子, 田中兴鄉 : 皮質万5の一例. Audiology Jap 20:316-324, 1977

11) Portman, M. \& Aran, J. M.: Potentiels cochléaircs obtenus chez l'homme en dehors 
de toute intervention chirurgicale. Rev Laryngol Otol Rhinol 88: 157-164, 1967

12) Sohmer, H. \& Feinmesser, M.: Cochlear and cortical audiometry. Conceniently recorded in the same subjects. Isr $J$ Med Sci 6: 219-223, 1970

13) Stark, A. \& Achor,L.J.:Auditory brain stem responses in neurological disease. Arch Neurol 32: 761-768, 1975

14) Starr, A. \& Hamilton, A. E.: Correlation between confirmed sites of neurological lesions and abnormalities of farfield auditory brain stem responses. Electroencephalogr Clin Neurophysiol 41: 595-608, 1976

15) Yoshie, N., Ohashi, T. \& Suzuki, T.: Nonsurgical recording of auditory nerve action potentials in man. Layngoscope 77: 76 85, 1967

16) Yoshie, N.: Clinical cochlear response audiometry by means of an average response computer. Rev Laryngol [Suppl] 646-672, 1971

17) Yoshie, N.: Diagnostic significance of the electrocochleogram in clinical audiometry. Audiology 12: 504-539, 1973 